The International

Journal of

Integrated

Engineering

\title{
Vibration Criteria Assessment due to Piling Works
}

\section{Tuan Norhayati Tuan Chik ${ }^{1 *}$, Cheng Sok Rou ${ }^{1}$, Ahmad Fahmy Kamarudin ${ }^{1}$, Seyed Jamalaldin Seyed Hakim ${ }^{1}$, Nor Azizi Yusoff ${ }^{2}$}

${ }^{1}$ Faculty of Civil Engineering and Built Environment,

Universiti Tun Hussien Onn Malaysia, 86400 Parit Raja, Johor, MALAYSIA

${ }^{2}$ Research Center for Soft Soil (RECESS),

Universiti Tun Hussien Onn Malaysia, 86400 Parit Raja, Johor, MALAYSIA

*Corresponding Author

DOI: https://doi.org/10.30880/ijie.2021.13.03.006

Received 22 September 2020; Accepted 09 March 2021; Available online 01 June 2021

\begin{abstract}
In the recent years, the level and nature of the ground vibrations has been more concerned in worldwide. Vibration affected on surrounding building is often associated with the vibration from the ground that is mainly caused by internal and external sources. One of the external sources is construction activities. Identify the effects of vibration caused by piling works in construction sites was the purpose of this paper. It is also aiming to determine the vibration criteria due to piling works in Klang Valley construction site. In addition, the objective of this study is to compare the level of vibration with Department of Environment (DOE) guideline between both Kajang MRT and Klang Valley MRT construction sites. The data used for this study is obtained from past researchers and field testing is performed by using Polytec Laser Doppler Vibrometer and Rion VM-55. The data has been analyzed by using ModalV of MATLAB software. Based on the results, it can be concluded that the vibration amplitude for three distance includes $5 \mathrm{~m}, 10 \mathrm{~m}$ and $20 \mathrm{~m}$ are located above the ISO level which stated that the area within the distances not suitable for placement of sensitive equipment. The highest value of root mean square velocity is occurred in the distance of $5 \mathrm{~m}$ and the reading is $80000 \mu \mathrm{m} / \mathrm{s}$. According to Department of Environment (DOE) guidelines, the vibration at distance of $1 \mathrm{~m}$ and $3 \mathrm{~m}$ at Kajang MRT will cause major damage to surrounding buildings while minor damage was produced by the vibration at $5 \mathrm{~m}, 10 \mathrm{~m}$ and $20 \mathrm{~m}$ distance from bored piling point which located around the area of Klang Valley MRT.
\end{abstract}

Keywords: Vibration, criteria, assessment, piling works

\section{Introduction}

Vibration affected on surrounding building is often associated with the vibration from the ground that is mainly caused by internal and external sources. Although the vibration taken by the ground is stronger than the building due to the direct transmission of vibration sources to the ground, the vibration on the building should also be taken care of as it would cause cosmetic damage and human discomfort even though the vibration on the building seems insignificant that the vibration cannot be felt physically by the occupants [1].

The external sources of vibration include operation of construction and traffic vehicles. Vibrations produced by construction work and road traffic are common concern in worldwide. In recent years, the urban developments in cities are growing rapidly causing the urbanization in the cities to become denser. In developing cities, many construction activities like piling have been carried out for building construction [2]. Due to the distance between the construction site and surrounding buildings is very close, the vibration effects caused by the piling works will be transmitted directly to the building surrounding it with high amplitude. 
Common internal source are sources produced from human activities like dancing and jumping exercises that happened in health clubs, stadium, dance floors and gymnasiums will lead to vibration of building [3]. These vibrations will result in a disruption to building users because of the annoying physical senses produced by human body. This is an unacceptable human safety condition [3]. The vibration problem becomes more serious and dangerous when the resonance happened. Resonance happens when the forced frequency is coincides with the natural frequency of the structure [4]. Resonance will cause more severe damages than the ordinary vibration. The information on the vibration can be obtained from the field testing by using the Laser Doppler Vibrometer. The data provided by past researchers have been analyzed by using MATLAB software and the results were compared with the vibration standard to obtain vibration limit on some specific buildings.

\section{Literature Review}

Environment pollutants are widely happening over these few decades. One of the environment pollutants included is the vibration disturbance. Urbanization of the cities has caused many constructions work such as piling works to be carried out which would lead to vibration disturbance. Therefore, the constructions work should always comply with the limit values to avoid ambient vibrations to occur. Within this framework, this contribution is intended to provide an overview about studies, guidelines and codes that include pertinent information on the selection of vibration criteria for heritage buildings [4]. As one of the main environmental pollutions, the vibration of environments, which seemed to have been tolerated in the past, is today increasingly being considered as a nuisance [5].

Vibration is defined as any motion that repeats itself after a time interval or it can be defined as oscillations of a system about a position of equilibrium. It exhibited a movement back and forth across the equilibrium point. The number of times that a complete motion takes place during the period of one second is called frequency which is measured in Hertz [6]. Some velocity-based vibration criteria refer to the components of the velocity vector which is the peak component particle velocity, whereas others refer to the module of the resultant vector which is the peak particle velocity [4]. Peak particle velocity (PPV) is the maximum instantaneous velocity of a particle at a point during a given time interval [7].

Vibration can be classified into several types which include free vibration, force vibration, linear vibration and non-linear vibration. A free vibration system will vibrate at one or more of its natural frequencies depending on the mass and stiffness distributions and also the boundary conditions [8]. Forced vibration refers to the motion of the system experiencing the continuing excitation whose magnitude varies sinusoidally with time [9]. Vibration is considered as linear vibration if all the basic components of vibratory system such as the spring the mass and damper are behaving linearly [10]. Non-linear occurs when one or more basic components of vibrating system are not behaving linearly. One of the examples for nonlinear vibration is the characteristics of vibration generated from pile driving vibrator [11].

The sources of vibration can be classified into continuous, impulsive and intermittent. Continuous vibration continues to be uninterrupted for a defined period. This type of vibration is assessed on the basis of weighted RMS (root mean square) acceleration values. Impulsive vibration also called transient vibration is a vibration that rapidly reaches to the peak value and subjected to resistance due to a damping effect that may involve several cycles of vibration [12]. Intermittent vibration can be defined as continuous vibration that varies significantly in magnitude due to disturbance [13]. Vibration that is generated during construction operations will cause effects on structures, sensitive devices and annoy people [14].

\subsection{Piling Works}

Piling work is often considered as the main sources of vibration in construction work. This is because the interaction between the ground and the foundation of the structure can have a major effect on building response. Vibration level will produced vary depending on different types of drilling equipment used in construction site. The use of more powerful machines from the increasing in mechanization which have the potential to cause high level of vibration [15]. Fig. 1 shows the wave system from a surface point source. P-waves will be generated within the shorter time compared with S-wave and R-wave as it travels faster than all other types of waves. P-waves which is considered as primary wave occurs in the form of compressional wave whereas $\mathrm{S}$-waves is known as shear wave which occurs in the form of transverse wave and R-waves occurs when part of the energy for both P-waves and S-waves is converted to surface waves.

\subsection{Vibration Criteria (VC Curve)}

Vibration criteria (VC curve) is used as a guidelines when design for facilities such as sensitive equipment in buildings[16]. This criteria are identified as a set of one third octave band velocity level from VC-A to VC-E as the sensitivity of people to sinusoidal vibration decreases with frequency are up to $40 \mathrm{~Hz}$ to $50 \mathrm{~Hz}$ and increases again due to chest wall and ocular globe resonate occurred [10].

The generic vibration criteria developed by Gordon [10] is then upgrade by Amick et al. [17] after several year. The version provided by Amick et al. [17] shows the criteria from VC-A with the largest value 50 $\mu \mathrm{m} / \mathrm{s}$ to the smallest 
value, $0.78 \mu \mathrm{m} / \mathrm{s}$ (VC-G) in Fig. 2. The application and range of VC limits including ISO criteria consider the safety level of vibration to human is stated in Error! Reference source not found.1. The detail size of the equipment is referred to line width in the case of microelectronics fabrication, the particle (cell) size in the case of medical and pharmaceutical research.

\subsection{Department of Environment (DOE), Malaysia Guideline}

The guideline provides the vibration limits for steady state vibration, short-term vibration and single event impulsive excitation in buildings. The vibration limit in the guideline does not guarantee the absence of damage but it can reduce the possibility for the damage to occur. The acceptance of the vibration is assessed against the potential structural damage in buildings [5]. Each of the range of vibration limit represents the level of the potential damage in buildings. Therefore, the recommended vibration limits can be used to estimate the effect of the vibration to the building.

Table 2 shows the recommended limits for damage risk in buildings from steady state vibration where there are four kinds of damage level which are safe, caution level, minor damage and major damage. It is recommended not to exceed the upper limit of caution level under normal circumstances.

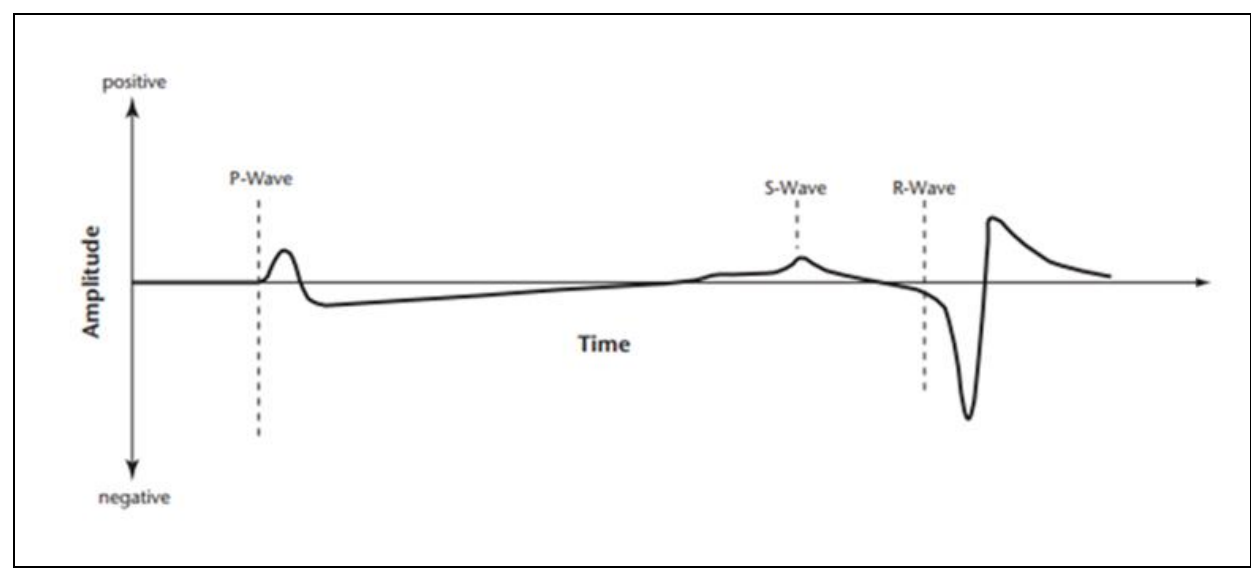

Fig 1 - Wave system from a surface point source [18]

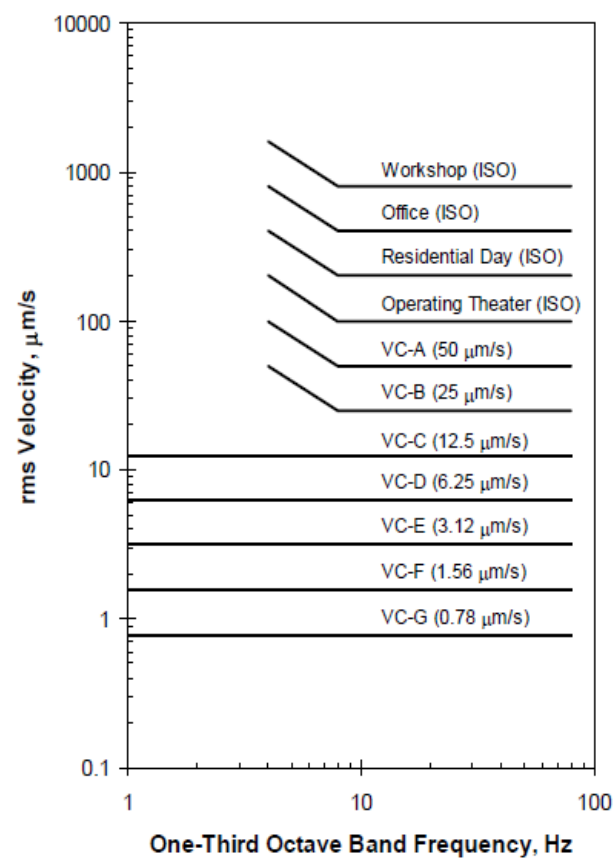

Fig. 2 - Generic vibration criterion (VC) curves for vibration-sensitive equipment, showing also the ISO guidelines for people in building [10 [17] 
Table 1 - Application and range of the vibration criteria curve [17]

\begin{tabular}{|c|c|c|c|}
\hline $\begin{array}{l}\text { Vibration } \\
\text { Curve }\end{array}$ & $\begin{array}{l}\text { Amplitude, } \\
\mu \mathrm{m} / \mathrm{s}\end{array}$ & $\begin{array}{c}\text { Detail size, } \\
\mu \mathrm{m}\end{array}$ & Application and experience \\
\hline Workshop (ISO) & 800 & N/A & $\begin{array}{l}\text { Distinctly perceptible vibration. } \\
\text { Appropriate to workshops and no } \\
\text { sensitive areas }\end{array}$ \\
\hline Office (ISO) & 400 & N/A & $\begin{array}{l}\text { Perceptible vibration. Appropriate to } \\
\text { offices and no sensitive areas. }\end{array}$ \\
\hline Residential day & 200 & 75 & $\begin{array}{l}\text { Barely perceptible vibration. Usually } \\
\text { adequate for computer equipment, } \\
\text { semiconductor probe test equipment, } \\
\text { and 20x microscopes. }\end{array}$ \\
\hline $\begin{array}{l}\text { Operating } \\
\text { theatre }\end{array}$ & 100 & 25 & $\begin{array}{l}\text { Vibration not perceptible. Suitable in } \\
\text { most microscopes to } 100 \mathrm{X} \text {. }\end{array}$ \\
\hline VC-A & 50 & 8 & $\begin{array}{l}\text { Adequate for most optical microscope } \\
\text { to } 400 \mathrm{X} \text {, microbalances, optical } \\
\text { balances, proximity and projection. }\end{array}$ \\
\hline VC-B & 25 & 3 & $\begin{array}{l}\text { Appropriate for inspection and } \\
\text { lithography equipment (including } \\
\text { steppers) to } 3 \mu \mathrm{m} \text { line widths. }\end{array}$ \\
\hline $\mathrm{VC}-\mathrm{C}$ & 12.5 & $1-3$ & $\begin{array}{l}\text { A good standard for lithography and } \\
\text { inspection equipment to } 1 \mathrm{~mm} \text { detail } \\
\text { size. }\end{array}$ \\
\hline VC-D & 6.25 & $0.1-0.3$ & $\begin{array}{l}\text { Suitable in most demanding equipment, } \\
\text { including electron microscopes (TEMs } \\
\text { and SEMs) and E-Beam systems. }\end{array}$ \\
\hline VC-E & 3.12 & $<0.1$ & $\begin{array}{l}\text { A difficult criterion to achieve in most } \\
\text { instances. Assumed to be adequate for } \\
\text { long-path laser-based interferometers } \\
\text { and other systems requiring } \\
\text { extraordinary dynamic stability. }\end{array}$ \\
\hline VC-F & 1.56 & N/A & $\begin{array}{l}\text { Appropriate for extremely quiet } \\
\text { research spaces. Not recommended for } \\
\text { use as a design criterion, only for } \\
\text { evaluation. }\end{array}$ \\
\hline VC-G & 0.78 & N/A & $\begin{array}{l}\text { Appropriate for extremely quiet } \\
\text { research spaces. Not recommended for } \\
\text { use as a design criterion, only for } \\
\text { evaluation. }\end{array}$ \\
\hline
\end{tabular}

Table 2 - Recommended limits for damage risk in buildings from steady state vibration [5]

\begin{tabular}{|c|c|}
\hline Damage Description & $\begin{array}{c}\text { Vertical Vibration Peak Velocity } v_{\max },[\mathrm{mm} / \mathrm{s}] \\
\text { (0 to Peak), }(10-100 \mathrm{~Hz})\end{array}$ \\
\hline Safe & Less Than 3 \\
\hline $\begin{array}{c}\text { Caution Level } \\
\text { (Damage Not Necessarily Inevitable) }\end{array}$ & 3 to 5 \\
\hline Minor Damage & 5 to 30 \\
\hline Major Damage & More Than 30 \\
\hline
\end{tabular}

\subsection{MATLAB (ModalV)}

MATLAB software is very popular in solving many kinds of engineering analysis problem by using different subprograms which include Choleski.m, adjust.m, truss3D.m and other. ModalV is a program developed by MATLAB software that is used to analyse the time history, spectrogram and one-third octave band spectra with vibration criteria. 
Hence, the value of vibration vertical velocity obtained from the vibration monitoring can be imported to MATLAB for further analysis in ModalV algorithm.

\section{Methodology}

A rapid development for public transportation infrastructure has been constructed in the Kuala Lumpur and Selangor in Malaysia. The construction site for Mass Rapid Transit (MRT) project which are Kajang MRT and Klang Valley MRT was selected as the location of the case study. The observing works was executed by past researchers which are Mohd Yatim [19] and Tumiran [20]. The monitoring vibration process in Kajang MRT has been done nearby Taman Cuepacs. Error! Reference source not found. shows the location of Taman Cuepacs and its nearby MRT stations and Taman Serdang Raya is where located nearby Klang Valley MRT. The reason of the selection is because of the availability of construction work which contribute construction induced vibration that could be evaluated by the vibration monitoring equipment.

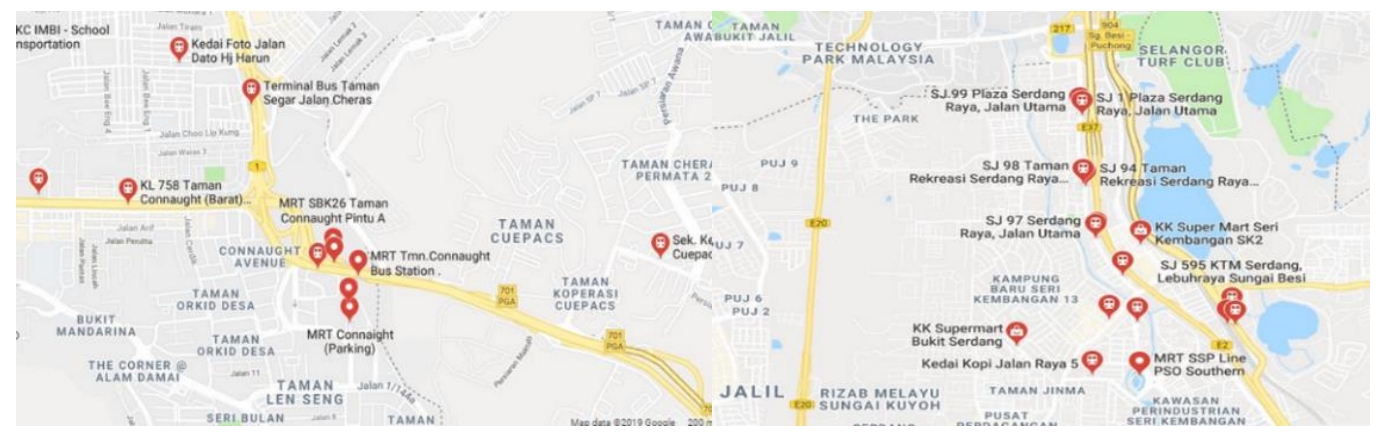

Fig. 3 - The location of Taman Cuepacs and Taman Serdang Raya

The construction involved at this site was bore piling for pier construction and it located next to the Cheras-Kajang Expressway. The buildings and facilities that are located around the bored pile construction in Kajang MRT included Petronas, Restoran Cerana and Cheras-Kajang Expressway could be affected by construction vibrations. Error! Reference source not found. shows the map location of nearby building and facilities [20]. Boring works for this construction is completed at $23 \mathrm{~m}$ depth. The measurement of operational vibration was taken at $1 \mathrm{~m}, 3 \mathrm{~m}, 10 \mathrm{~m}$, and $20 \mathrm{~m}$ apart from the vibration source by using measuring tape.

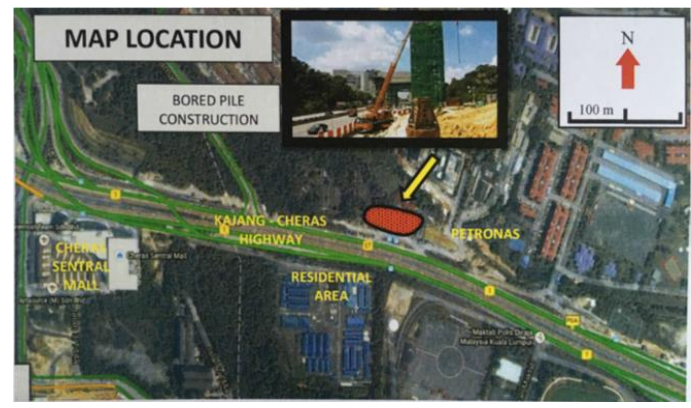

Fig. 4 - Map location of Kajang MRT construction site [20]

Three monitoring location have been identified during bored piling activities which located in Selangor state was chosen as second location. Taman Serdang Raya is located alongside the Klang Valley MRT which extends from Sungai Buloh to Putrajaya. The buildings that are located around include commercial and residential area. The distance between bore pile location and monitoring point was taken at $5 \mathrm{~m}, 10 \mathrm{~m}$ and $20 \mathrm{~m}$. The commercial block around construction site as shown as Error! Reference source not found. 


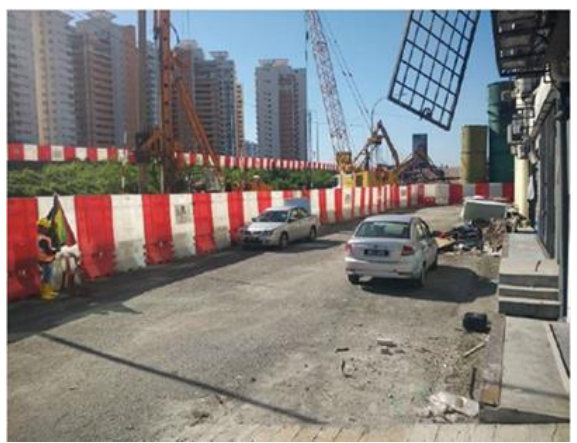

Fig. 5 - Commercial block around construction site in Taman Serdang Raya [19]

\section{Results and Discussions}

First and foremost, the data performed by past researchers need to be classify by using Microsoft Excel and analysed by using the software called MATLAB software. This software has been used to analyse the data to achieve the VC curves assessments. Lastly, the peak particle velocity (PPV) based on distances have been compared with Department of Environment (DOE) guidelines to identify the damage contributed from bored pile activities.

\subsection{Bored Pile Results for Taman Cuepacs}

From the result provided by Tumiran [21], he stated that the result were not collected for 2 hours of monitoring work. Alternately, the results only included the time where the bore piling activities which is hydraulic boring machine (Bauer BG 28) is activated. Error! Reference source not found. shows the measurement gathered from the Tumiran [20]. Five trails have been taken for the distance of $1 \mathrm{~m}, 3 \mathrm{~m}, 10 \mathrm{~m}$ and $20 \mathrm{~m}$ respectively. There are some outlier values that can be seen from the table. These may due to outside factors like vibration of a large vehicle from the highway nearby during the measurement. Thus, the average value for each distance is calculated for more accurate analysis.

The vibration velocity has decreased significantly as the distance increases. This is due to the effect of attenuation which is the decay of vibration over distance. The decay is caused by the dissipation of energy which is the material damping and the geometric damping which is the spreading of the wave fronts over an increasing area. In other words, there is a loss of energy over distance as the energy is absorbed by the soil during propagation. However, the type of soil is not taken into consideration in this study as the measurement is taken from the same site and during the same day. Thus, other unpredictable factors like weather which may affect the condition of soil can be ruled out.

Table 3 - Tabulation of data for bore piling work by hydraulic boring machine (Bauer BG28)

\begin{tabular}{ccccccc}
\hline $\begin{array}{c}\text { Distance } \\
(\mathbf{m})\end{array}$ & \multicolumn{6}{c}{ Vibration velocity $(\mathbf{m m} / \mathbf{s})$} \\
\cline { 2 - 7 } & $\mathbf{1}$ & $\mathbf{2}$ & $\mathbf{3}$ & $\mathbf{4}$ & $\mathbf{5}$ & Average \\
\hline 1 & 30.0 & 32.4 & 67.4 & 41.4 & 22.4 & 38.72 \\
3 & 28.6 & 26.8 & 26.8 & 23.7 & 53.5 & 35.54 \\
10 & 24.6 & 23.0 & 23.0 & 11.8 & 17.0 & 24.58 \\
20 & 7.91 & 14.0 & 14.0 & 12.2 & 9.29 & 10.82 \\
\hline
\end{tabular}

Based on the table above, a log-log graph is plotted dispersedly according to respective distance as shown in Fig. . A line of best fit is obtained by using the average value for all the distance and a straight inverse line can be seen. The regression value $\mathrm{R}^{2}$ which can represent the reliability of the equation is shown to be 0.978 . It can be seen that the average vibration velocity for the $1 \mathrm{~m}$ and $3 \mathrm{~m}$ is way over the recommendation limit of $30 \mathrm{~mm} / \mathrm{s}$ for damage risk in building as prescribed by Department of Environment Malaysia, Vibration Limit and Control in the Environment and can cause major damage to the surrounding buildings. 


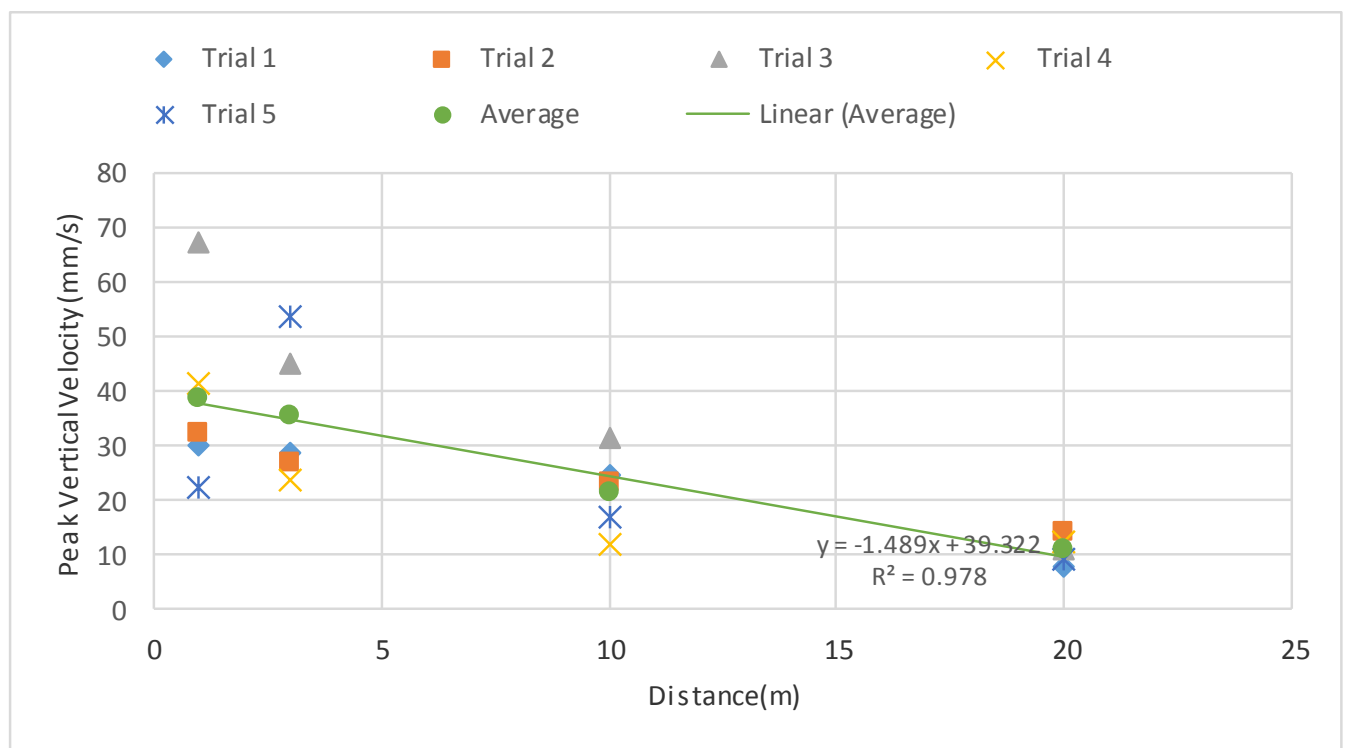

Fig. 6 - Peak vertical velocity against distance for bore piling work (Bauer BG28)

\subsection{Bored Pile Results for Taman Serdang Raya}

The vibration testing for bored piling activities at Taman Serdang Raya were collected by past researcher, Mohd Yatim [19]. According to Mohd Yatim [19], he states the results were not covered for 24 hours of monitoring and the monitoring process were conducted when the piling works under operation. The monitoring of vibration has been carried out at three different distances from the bored piling point which are $5 \mathrm{~m}, 10 \mathrm{~m}$ and $20 \mathrm{~m}$.

Error! Reference source not found.(a) shows the graph of acceleration versus time for $5 \mathrm{~m}$ distance apart from the bored piling point. The graph of vibration response with time history has time domain ranging from 0s to 10s. This graph was generated directly from subprogram of MATLAB software called rlistout.m. From the figure, it can be seen that the peak value of acceleration happened around $2 \mathrm{~s}$ and $7 \mathrm{~s}$ which is around $20 \mathrm{~mm} / \mathrm{s}^{2}$. Peak reading happened when the boring machine is drilling a hole for bored pile casting. The peak value of $20 \mathrm{~mm} / \mathrm{s}^{2}$ which is considered high occurs due to the monitoring point is closer to the vibration source. In time interval of $4 \mathrm{~s}$ to $7 \mathrm{~s}$, the amplitude reading is considered as ambient vibration when the boring machine is removing excessive soil to the surface.

The graph of acceleration versus time for $10 \mathrm{~m}$ distance is illustrated in Error! Reference source not found.(b). Based on the graph, the peak amplitude occurs in around $2 \mathrm{~s}$ and the reading is $10.2 \mathrm{~mm} / \mathrm{s}^{2}$. When the time at $3 \mathrm{~s}$ and $8 \mathrm{~s}$, the amplitude of vibration is $9.5 \mathrm{~mm} / \mathrm{s}^{2}$ which considered as second highest amplitude.

Error! Reference source not found.(c) shows the graph of acceleration versus time for $20 \mathrm{~m}$ distance apart from the bored piling point. From the graph, it can be seen that the highest amplitude reading happened in $4 \mathrm{~s}$ and $9 \mathrm{~s}$, the value of reading is $7.2 \mathrm{~mm} / \mathrm{s}^{2}$. For the second highest amplitude which is $6.5 \mathrm{~mm} / \mathrm{s}^{2}$, it occurs at the time of $2 \mathrm{~s}$. The amplitude was followed by $3 \mathrm{~mm} / \mathrm{s}^{2}$ at around $7 \mathrm{~s}$.

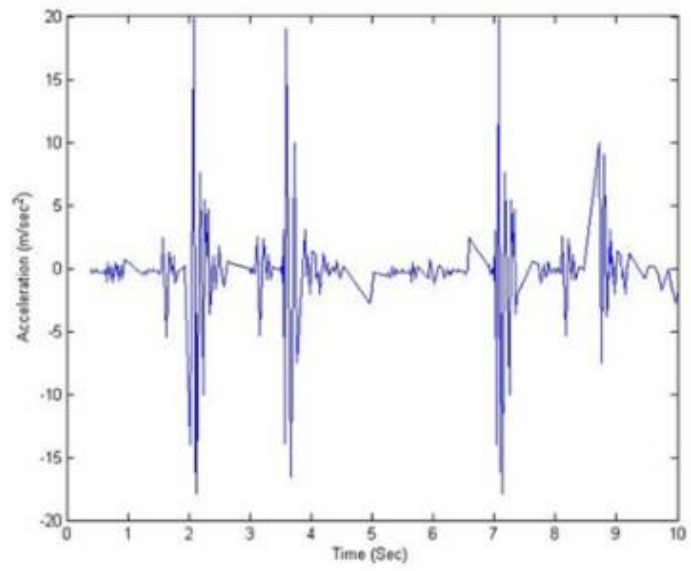

(a) $5 \mathrm{~m}$ distance

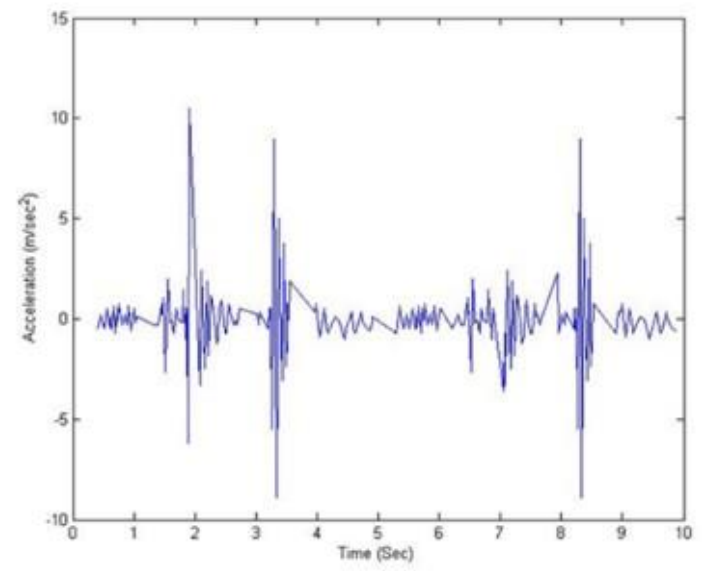

(b) $10 \mathrm{~m}$ distance 


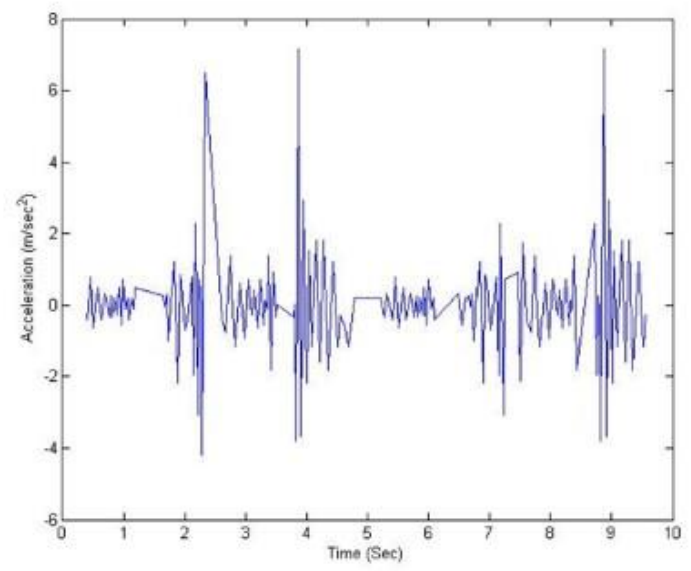

(c) $20 \mathrm{~m}$ distance

Fig. 7 - Time history graph (acceleration versus time) at different distance from piling point

Fig. 8 shows the graph of time history (velocity versus time), spectrogram and frequency that generated by ModalV program. Time history, spectrogram and frequency graph for $5 \mathrm{~m}$ distance measured from piling point are produced by MATLAB analysis and is shown in Error! Reference source not found.(a). The amplitude is considering highest in $10 \mathrm{~Hz}$ and zero amplitude occurred around 4 to $5 \mathrm{~Hz}$. At the low frequency reading where there is a little vibration exist, the spectrogram appeared in light blue colour whereas red colour indicated the highest frequency produced by bored pile activities. Hence, it shows that the high amplitude occurs when the time is at $1.5 \mathrm{~s}, 3 \mathrm{~s}$ and $6.5 \mathrm{~s}$ and the frequency is at $10 \mathrm{~Hz}$.

Error! Reference source not found.(b) displays time history, spectrogram and frequency graph in the distance of $10 \mathrm{~m}$. The amplitude is considering highest in $9 \mathrm{~Hz}$ and lowest amplitude is at the frequency range of $0-5 \mathrm{~Hz}$. Based on the spectrogram, the high amplitude occurs when frequency is $9 \mathrm{~Hz}$ and the time is $1.5 \mathrm{~s}, 3 \mathrm{~s}$ and $8 \mathrm{~s}$. Blue colour which indicated low amplitude occurs when the time between 0 to $1 \mathrm{~s}$ and 4 to $6 \mathrm{~s}$. The blue colour part in $10 \mathrm{~m}$ has higher intensity than in the distance of $5 \mathrm{~m}$ due to decay of vibration during wave's propagation.

The graph of time history, spectrogram and frequency in the distance of $20 \mathrm{~m}$ is presented in Error! Reference source not found.(c). The amplitude is considering highest in $8 \mathrm{~Hz}$ and lowest amplitude is at the frequency range of 0 $5 \mathrm{~Hz}$. In the spectrogram, the high amplitude occurs when frequency is $8 \mathrm{~Hz}$ and the time is at $3 \mathrm{~s}$ and $9 \mathrm{~s}$ while low amplitude occurs when the time between 0 to $1 \mathrm{~s}, 2.5 \mathrm{~s}, 5$ to $6 \mathrm{~s}$ and 7 to $8 \mathrm{~s}$. According to International Standard (2001), it shows that the body of occupants are received less sensitive to vibration when the frequency is below $8 \mathrm{~Hz}$. The red colour part in $20 \mathrm{~m}$ has lower intensity than in the distance of $5 \mathrm{~m}$ because the impact from piling work is weaker at $25 \mathrm{~m}$ distance.
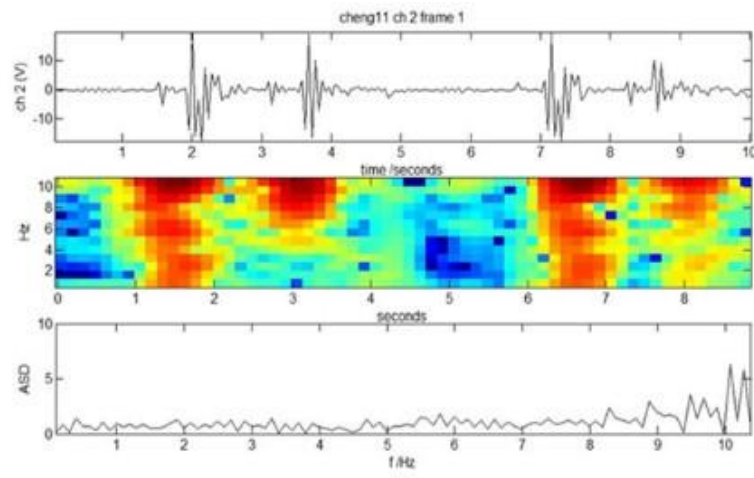

(a) $5 \mathrm{~m}$ distance
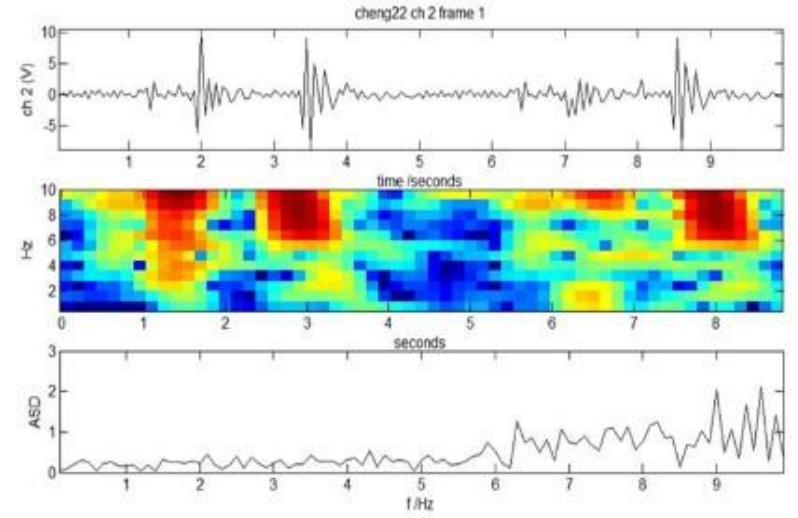

(b) $10 \mathrm{~m}$ distance 


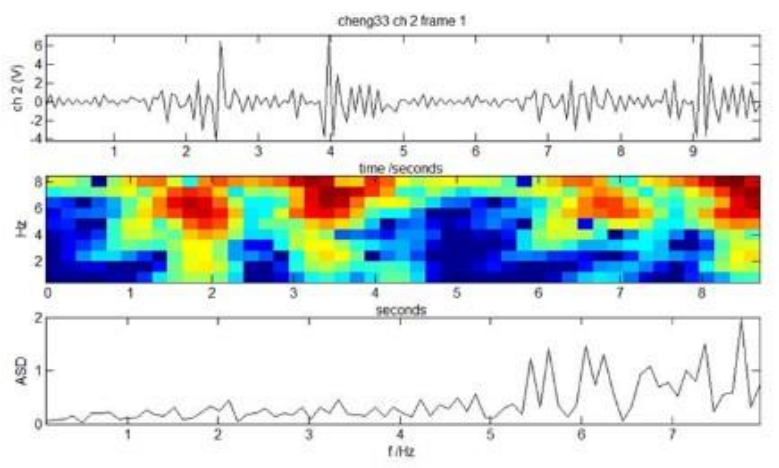

(c) $20 \mathrm{~m}$ distance

Fig. 8 - The graph of time history (velocity versus time), spectrogram and frequency at different distance from piling point

Error! Reference source not found. shows the one-third octave band frequency graph with vibration criteria (VC) curve at $5 \mathrm{~m}, 10 \mathrm{~m}$ and $20 \mathrm{~m}$ distance from vibration source. From the Fig. 9(a)-(c), it clearly shows that the vibration amplitude is above the ISO level which is $800 \mu \mathrm{m} / \mathrm{s}$ when compared with Gordon [10] and Amick vibration criteria [17].

\subsection{Comparison Between Klang Valley MRT and Kajang MRT Project}

In the construction project of Klang Valley MRT and Kajang MRT, the pile used for both constructions is the bored pile and the machinery used in the piling work is vibratory pile driver. However, the vibration amplitude induced by the piling work from these two construction sites are different. At Kajang MRT site, the peak particle velocity at $1 \mathrm{~m}$, $3 \mathrm{~m}, 10 \mathrm{~m}$ and $20 \mathrm{~m}$ distance are $38.72 \mathrm{~mm} / \mathrm{s}, 35.54 \mathrm{~mm} / \mathrm{s}, 24.58 \mathrm{~mm} / \mathrm{s}$ and $10.82 \mathrm{~mm} / \mathrm{s}$ respectively. Meanwhile, the peak particle velocity in Klang Valley MRT site at $5 \mathrm{~m}, 10 \mathrm{~m}$ and $20 \mathrm{~m}$ distance are $20 \mathrm{~mm} / \mathrm{s}, 10.2 \mathrm{~mm} / \mathrm{s}$ and $7.2 \mathrm{~mm} / \mathrm{s}$ respectively. Hence, it can be seen that the vibration amplitude in Kajang MRT site is higher than in the Klang Valley MRT site. This is probably due to the location of Kajang MRT site is near to the Cheras-Kajang expressway which has high speed vehicle driving through it during the construction process resulting in contribution of vibration from vehicle.

Based on DOE guideline, the vibration at a distance of $1 \mathrm{~m}$ and $3 \mathrm{~m}$ at Kajang MRT site will cause major damage to surrounding buildings whereas vibration at the $10 \mathrm{~m}$ and $20 \mathrm{~m}$ distance from the vibration source will contribute minor damage to buildings. As for Klang Valley site, minor damage will be caused by the vibration at $5 \mathrm{~m}, 10 \mathrm{~m}$ and $20 \mathrm{~m}$ distance as the peak particle velocity of these three distances are within $5 \mathrm{~mm} / \mathrm{s}$ to $30 \mathrm{~mm} / \mathrm{s}$.

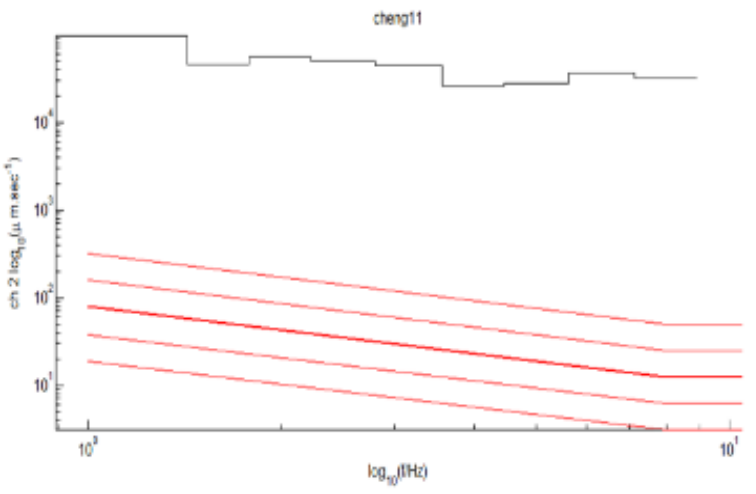

(a) 5m Distance

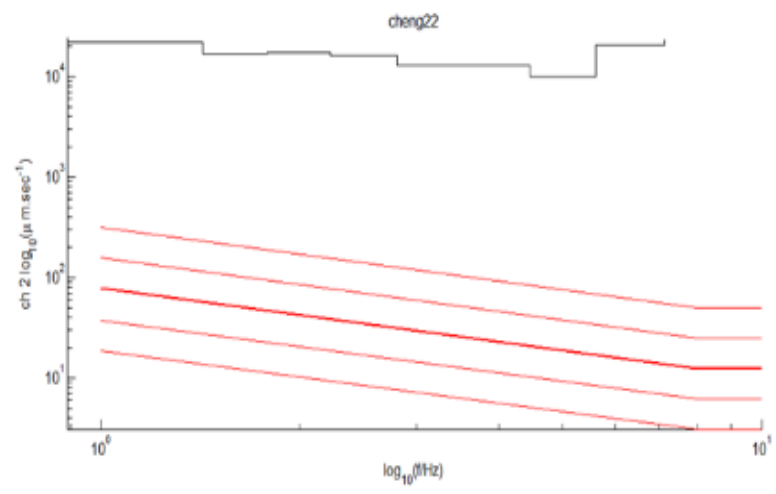

(b) $10 \mathrm{~m}$ Distance 


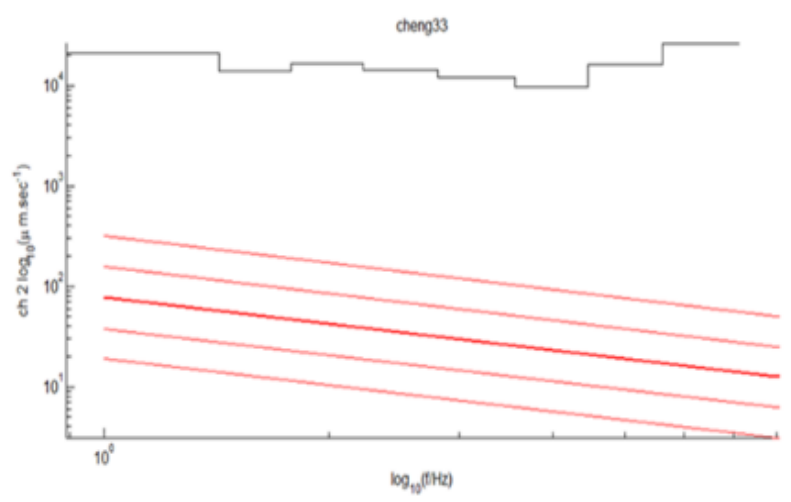

(c) $20 \mathrm{~m}$ Distance

Fig. 9 - One-third octave band frequency graph with VC curve at different distance from piling point

\section{Conclusions}

As a conclusion, the data obtained from past researcher has been analysed by using MATLAB software. The methodology that has been used to illustrate the vibrations associated with bored pile activities in order to evaluate the amplitude of vibration that occurred at any distance from the source for a particular set of locations. The one-third octave band frequency has been obtained to compare with standard vibration guideline which is Gordon Vibration Criteria. It can be concluded that the vibration amplitude for three distance includes $5 \mathrm{~m}, 10 \mathrm{~m}$ and $20 \mathrm{~m}$ are above the ISO level. The highest value of root mean square velocity is happened in the distance of $5 \mathrm{~m}$ and the reading is 80000 $\mu \mathrm{m} / \mathrm{s}$. According to Department of Environment (DOE) guidelines, the vibration at distance of $1 \mathrm{~m}$ and $3 \mathrm{~m}$ at Kajang MRT will cause major damage to surrounding buildings and peak particle velocity are $38.72 \mathrm{~mm} / \mathrm{s}$ and $35.54 \mathrm{~mm} / \mathrm{s}$ respectively. However, minor damage will be created by the vibration at $5 \mathrm{~m}, 10 \mathrm{~m}$ and $20 \mathrm{~m}$ distance from bored piling point that located around the area of Klang Valley MRT. The reading of peak particle velocity of these three distances are within $5 \mathrm{~mm} / \mathrm{s}$ to $30 \mathrm{~mm} / \mathrm{s}$. The vibration will cause major and minor damage to surrounding building and the vibration criteria analysis shows that the area within the distances are not suitable for placement of sensitive equipment. Lastly, the results have indicated that the decay of vibration increased with distance.

\section{Acknowledgment}

The authors would like to thank the Faculty of Civil Engineering and Built Environment and Research Center for Soft Soil (RECESS), Universiti Tun Hussien Onn Malaysia, Parit Raja, Johor.

\section{References}

[1] de Azevedo F. S. \& Patricio J. (2004). Annoyance and damage in buildings caused by vibrations. Considerations for a Vibration Control Good Practice. http://www.sea-acustica.es/fileadmin/publicaciones/Guimaraes04 _ID103.pdf

[2] Taillefer N., Villot M., Jean P. \& Nguyen H. H. (2011). Vibration due to construction : A case study. Proceedings of the 8th International Conference on Structural Dynamics (EURODYN 2011), Leuven

[3] Allen D. E. (1990). Building vibrations from human activities. Concrete International, 12(6), 66-73

[4] Fumagalli F., Marano G. C., Monti G., Quaranta G., Rea R. \& Nazzaro B. (2013). Effects of ambient vibrations on heritage buildings: Overview and wireless dynamic monitoring application. Proceeding of the 3rd International Workshop Dynamic Intercation Betwwen Soil, Monuments and Built Environment, Rome

[5] Department of Environment (2007). The Planning Guideline for Vibration Limit and Control in the Environment. Putrajaya

[6] Rahman A. A. (2009). Theoretical Model for Damage and Vibration Response in Concrete Bridges. Final Research Report, Universiti Teknologi Malaysia

[7] BS7385-1 (1993) (1993). Evaluation and Measurement for Vibration in Buildings - Part 2: Guide to Damage Levels from Groundborne Vibration. British Standards Institution

[8] Wang C. (2010). Structural Vibration. Taylor and Francis Group

[9] Harris C. M. \& Piersol A. G. (1962). Harris' Shock and Vibration Handbook. McGraw-Hil

[10] Gordon C. G. (1999). Generic vibration criteria for vibration sensitive equipment. International Society for Optical Engineering (SPIE) Conference on Current Developments in Vibration Control for Optomechanical Systems, Denver, pp. 22-33

[11] Abdel-Rahman S. M. (2011). Vibration associated with pile driving and its effects on nearby historical structures. IMAC-XX: Conference and Exposition on Structural Dynamics, pp. 1251-1258 
[12] Hamidi A., Pourjenabi M. \& Rooz A. F. H. (2018). Allowable distance from impact pile driving to prevent structural damage considering limits in different standards. Practice Periodical on Structural Design and Construction, https://doi.org/10.1061/(ASCE)SC.1943-5576.0000354

[13] Department of Environment and Conservation (2006). Assessing Vibration: A Technical Guideline. Department of Environment and Conservation, Sydney

[14] Svinkin M. R., Gordon S. A. \& Williams D. (2005). Vibration environmental effects of construction operations. Geotechnical Engineering Resources Education Materials, 26, 1-13

[15] BS5228-2 (2009). Code of Practice for Noise and Vibration Control on Construction and Open Sites-Part 2: Vibration. Bristish Standard Institution

[16] Tuan Chik T .N., Brownjohn J. M. \& Petkovski M. (2010). Finite element analysis of ground borne vibrations in sensitive buildings using inputs from free field measurements. Proceedings of ISMA2010 International Conference on Noise and Vibration Engineering, Leuven, pp. 759-772

[17] Amick H., Gendreau M., Busch T. \& Gordon C. G. (2005). Evolving criteria for research facilities: Vibration. Proceedings of SPIE Conference 5933: Buildings for Nanoscale Research and Beyond, San Diego

[18] Woods R.D. (1997). Dynamic Effects of Pile Installations on Adjacent Structures. National Cooperative Highway Research Program

[19] Mohd Yatim M. H. (2018). An Investigation on Vibration Impact During Construction Bore Piling Activity on Public Receptors in Klang Valley Mass Rapid Transit Serdang Project. Research Project Report, University of Malaya

[20] Tumiran M. T. (2015). Analysis on Vibration Monitoring at MRT Infrastructure Construction Site. Master Thesis, Universiti Tun Hussein Onn Malaysia 